Volume and Issues Obtainable at Center for Sustainability Research and Consultancy

Journal of Accounting and Finance in Emerging Economies

ISSN: 2519-0318 \& ISSN (E): 2518-8488

Volume 7: Issue 2 June 2021

Journal homepage: www.publishing.globalcsrc.org/jafee

\title{
Anticipating Bankruptcy for Non-financial Sector Firms: A Case of Pakistan
}

*Sana-ur-Rehman, Department of Business Administration, NFC-Institute of Engineering and Technology, Multan, Pakistan

Hani Baloch, Institute of Management Sciences, University of Balochistan, Quetta, Pakistan

Abdul Qayyum, Faculty of Management Sciences, Riphah International University, Islamabad, Pakistan

*Corresponding author's email: dr.sana.ur.rehman@gmail.com

ARTICLE DETAILS
History
Revised format: May 2021
Available Online: Jun 2021

\section{Keywords}

Bankruptcy, Z-score, $O$ -

Score, Non-financial

Sector, Bankruptcy

prediction

JEL Classification

M40, M41

\section{ABSTRACT}

Purpose: This paper attempts to identify the relevance and strength of financial ratio based analysis models called Z-Score and O-Score for bankruptcy determination of non-financial sector of Pakistan. The study aims to suggest a best model for future researchers and analysts to predict company's bankruptcy.

Design/Methodology/Approach: Comparative analysis is employed to determine the accuracy of bankruptcy predictability by considering the sample of 20 bankrupt/suspended nonfinancial Pakistani firms during 2015 to 2017.

Findings: Result estimates of both models show that both models are significant predictors when applied to Pakistan's nonfinancial sector firms. There is no significant difference in respective predictive abilities. Subsequently this analysis suggests that instead of applying both the models future analyses and researchers can directly select any one of the model to predict survival of the firm.

Implications/Originality/Value: Financial analysts may select any one among Z-Score and O-Score models for bankruptcy prediction.

(C) 2021 The authors, under a Creative Commons Attribution-Non

Commercial 4.0

Recommended citation: Rehman, S., Baloch, H. and Qayyum, A. (2021). Anticipating Bankruptcy for Non-financial Sector Firms: A Case of Pakistan. Journal of Accounting and Finance in Emerging Economies, 7(2), 409-417

\section{Introduction}

Out of many definitions about Bankruptcy, definition by Pongsatat et al. (2004) stands most popular. According them Bankruptcy "is an inability of a company to continue operations because of high debt obligations". Bankruptcy rate of companies in a county plays an important part in determining the economic performance outlook for international community, investors and creditors. Bankruptcy plays a role of economy's plumbing that allows the market to flush away the inefficient businesses and reallocate capital to efficient businesses. Pakistan as a country has faced many political and socio-economic problems that resulted in failure of many corporations. In past, two decades a large number of financial as well as non-financial companies, 
are declared bankrupt and/or delisted by Pakistan Stock Exchange, SECP or closed up working due to court orders i.e. violation of listing regulation no. 32 (1) (d). Therefore, it is most important to predict such companies that are going to bankrupt in future. It may help creditors, investors, suppliers, academicians and customers to know in advance about companies' future performance and may safe investments from future loss. Most countries have bankruptcy laws but they vary from country to country based on respective legal systems. Laws are just considered as pieces of paper. Giving life to laws require an entire legal infrastructure, vigor, implementation, and strong monitoring.

Monitoring bankruptcies is important from economic growth perspective as bankruptcies discourage the creditors and international investors. According to the game theory plan, a debtor is mostly of the opinion and has intensions of not to repay the debt. Every creditor knows this fact and their best move could be not to lend, but in case of non-lending or minimum lending the economic growth of creditor/lender remains stagnant and the same could have impact on overall performance of the country's financial sector.

Looking at literature many researchers has used accounting ratios for predicting bankruptcy in different countries. Multiple analyses and techniques are used while investigating firm's performance, profitability, and bankruptcy. Ratio comparisons widely used by practitioners to analyze market and business position but at the same time has gained much criticism from the relevance and significance of such analysis. To address this gap Edward Altman(1968) and James Ohlson (1980) have introduced two bankruptcy predicting models, one Z-Score and second OScore. Both models are developed on the bases of multiple discriminant analysis (MDA). These models are helpful to determine the patterns of linear combinations of objects classified and separated by two or more groups or events. Both models are widely being used for analyzing and predicting corporate bankruptcy.

Many experts had compared different techniques of measuring bankruptcy by suggesting different predicting models. Furthermore, several studies have been investigated and used Z-score model. In 1995, this model was utilized to analyze the credit forwarded to the companies of emerging markets. An empirical study by Beaver's (1966) also found significant results while predicting company's financial distress. Studies by Francis (1990), Han, Jenning and Noel (1992), Griffen and Lemmon (2002), Stone (1991), Dichev (1998), and many others have utilized Z- Score for their studies as it yielded significant results. Besides this, many researchers have studied another predictive model called O-Score and found it a better forecaster than Z-Score Begley et al., (1996).

Present study attempts to identify the accounting base model, considered as utmost important in predicting bankruptcy for the firms in non-financial sector of Pakistan. Numerous empirical works have predicted bankruptcy through different approaches. This study tries to find out which accounting base technique provides more significant result in case of Pakistani setup. Comparative analysis of logit model Ohlson's O-Score and Altman's Z-Score Multiple Discriminant Analysis (MDA) has been applied by considering previous research and literature. Twenty non-financial companies of Pakistan, that were declared bankrupt, regardless the reason of bankruptcy, during the year 2015 to 2017 are taken as sample for analysis. The paper aims to find weather these models are able to significantly determine the financial failure as the reason of bankruptcy.

\section{Literature Review}

Since 1960s and specifically after 70's and 80's financial crises investigators have devoted much time and efforts to examine the bankruptcy forecast for different companies across the globe. Among others some of the researchers such as, Altman and Lavelle (1981) from Canada, Izan 
(1984) from Australia, Charitou et al (2004) from UK, Micha ( 1984) from France, Xu and Zhang (2008) from Japan, Bidin (1988) from Malaysia, Altman et al (1995) from Korea, Eljelly et al (2001) from Sudan, Ugurlu and Aksoy ( 2006) from Turkey, Etemadi et al., (2008) from Iran and Bandyopadhyay (2006) from India have done extensive work.

Bankruptcy being a global problem exists in developed as well as developing countries alike. However, its occurrence is higher in developing countries as compare to developed countries. In addition to bankruptcy other causes behind corporate failures are capital structures variances, no compliance of accounting standards and/or uncertainties in social, political, and economic environments (Argenti, 1976, Newton, 1985, Her \& Choe, 1999).

Revolutionary work by Beaver (1966) is considered as providing a foundation model for insolvency forecast. Beaver's framework contends that a company is viewed as a pool of resources where liquid assets source, especially, inflows and outflows play important role. According to him insolvency of a firm is also considered in terms of inflows and outflows. If firm's pooled resources have more outflows then inflows, a point may come when a firm becomes incapable to return its obligations at the time of maturity. On the bases of such argumentations Beaver's four propositions are stated below:

1. Larger pool leads towards less probability of failure.

2. If net liquid-asset inflow is higher from operations, lesser will be the insolvency probability.

3. The company holding larger amount of debt has higher chance of failure.

4. The larger amount of the firm's operational expenditure, leads toward the greater probability of failure.

According to Beaver (1966) thirty ratios are considered most appropriate to capture pertinent aspects of insolvency with respect to univariate discriminant investigation. These thirty ratios are applied by Beaver to 79 pairs of non-bankrupt and bankrupt organizations. The best discriminators found were working capital funds flow divided by total assets and return on assets. His frame work was able to correctly determine $88 \%$ to $90 \%$ bankrupt cases.

Altman (1968) study applies an analysis called multivariate discriminant technique combining with seven different financial ratios to a group non-bankrupt and bankrupt companies. Altman was able to determine approximately $90 \%$ of the insolvency cases a year before the firms' failures.

Ohlson (1980) is another well-known researcher introduced to use logit analysis technique for the company's insolvency prediction problem. In order to validate his model, 105 bankrupt companies and 2058 non-bankrupt companies are used as a sample. He concludes that in the previous studies where insolvency predictive power has been used results were probably less appropriated.

Artificial intelligence technique has also been used as insolvency predictor in countries such as Greece and Iran. Work by Etemadi et al. (2008) on multiple discriminant analysis technique and genetic programming remained helpful to anticipate the possibility of default in Iranian firms. Their work suggests that genetic programming provides default prediction more accurately.

A case study by Zanakis and Zopounidis (1997) focusing the financial variables of acquired and non-acquired companies of Greek is unable to generate clear results due to the use of analogous financial ratio for both acquired companies and non-acquired companies. Not only these, but researchers also have used other kinds of AI techniques while suggesting alternate models for insolvency prediction. 
A study by Pongsatat et al. (2004) investigates the bankruptcy prediction capability presented by Ohlson's and Altman's for large and small firms of Thailand. Which concludes that Altman's model shows a greater predictive accuracy of firms' bankruptcy than the model by Ohlson. Likewise, for Indian firms Bandyopadhyay (2006) uses logit and Z-score based model with 91\% of high classification power to predict company's possible failure to pay. Moreover, influenced by Altman's (1968) and Ohlson's (1980) statistical techniques as used by Ugurlu and Aksoy (2006) are able to predict bankruptcy of some Turkish companies.

After thorough literature review and above mentioned discussion we propose the hypothesis that Z-score is equally good predictor of bankruptcy than O-Score.

\section{Research Methodology}

Z-score and O-score models used in this study predict bankruptcy of the 20 nonfinancial companies delisted by Pakistan Stock Exchange (PSE). Delisting by PSE has been done during 2015-2017 because of the different reasons as mentioned in Table 1. Execution of liquidation performed due to the courts orders asking for the winding up businesses under the regulation No. 32 (1) (d) of SECP violation. The data of bankrupt/suspended firms has been used for estimations purpose. Both, Z-Score and O-Score, techniques have been applied on the data to find out whether these models are able to predict bankruptcy and which predictor provides most significant results.

Table 1. List of Companies with Reason and Years of Suspension

\begin{tabular}{|c|c|c|c|}
\hline $\begin{array}{l}\text { S. } \\
\text { No. }\end{array}$ & Company's Name & Year & Reasons for Suspension \\
\hline 1 & Brothers Textile Mills Ltd & 2017 & $\begin{array}{l}\text { Clause No. 5.11.1. (e) of the regulations of PSX was not satisfied i.e. } \\
\text { related with outstanding dues of PSX. Clause No. 5.11.1. (f) was not } \\
\text { fulfilled i.e. comply with the requirement of "Listing of companies } \\
\text { and Securities Regulations". }\end{array}$ \\
\hline 2 & Pangrio Sugar Mills Ltd & 2017 & Non declaration of profit / rental payments \\
\hline 3 & $\begin{array}{l}\text { Abdullah Shah Ghazi Sugar } \\
\text { Mills Limited }\end{array}$ & 2017 & $\begin{array}{l}\text { Annual General Meetings were not held for more than } 2 \text { years as } \\
\text { required under PSX Regulations clause No 5.11.1.(b) }\end{array}$ \\
\hline 4 & Associate Services Limited & 2016 & $\begin{array}{l}\text { Amalgamation of Associated Services Ltd into Macter International } \\
\text { Limited }\end{array}$ \\
\hline 5 & Azgard Nine Ltd (TFC) & 2016 & Non-Payment of profit/mark-up/interest \\
\hline 6 & ICC Textile Limited & 2016 & $\begin{array}{l}\text { Requirement of PSX regulation's Clause No. 5.11.1. (e) was not } \\
\text { fulfilled, i.e. Payment of outstanding dues related to PSX annual } \\
\text { listing }\end{array}$ \\
\hline 7 & Suhail Jute Mills Ltd & 2016 & -do- \\
\hline 8 & $\begin{array}{l}\text { Southern Electric Power Co. } \\
\text { Limited }\end{array}$ & 2016 & -do- \\
\hline 9 & 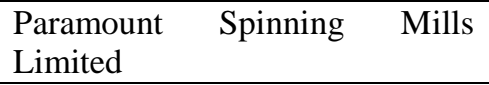 & 2016 & -do- \\
\hline 10 & Mukhtar Textile Mills Ltd & 2016 & -do- \\
\hline 11 & Gulshan Spinning Mills Ltd & 2016 & -do- \\
\hline 12 & Gulistan Spinning Mills Ltd & 2016 & -do- \\
\hline 13 & Fateh Sports Wear Limited & 2016 & -do- \\
\hline 14 & Fateh Industries Limited & 2016 & -do- \\
\hline 15 & Ali AsgharTextileMills Ltd & 2016 & -do- \\
\hline 16 & Apollo Textiles Mills Limited & 2015 & -do- \\
\hline 17 & Pace (Pakistan) Ltd (TFC) & 2015 & $\begin{array}{l}\text { Unable to submit the re-structuring / revised redemption fee } \\
\text { according to the schedule. }\end{array}$ \\
\hline 18 & $\begin{array}{l}\text { Mandviwala Mauser Plastic } \\
\text { Industries Limited }\end{array}$ & 2015 & In process of rectification of defaults \\
\hline 19 & $\begin{array}{l}\text { Dadabhoy Cement Industries } \\
\text { Limited }\end{array}$ & 2015 & $\begin{array}{l}\text { Failed to satisfy the PSX Regulation's requirement of clause } \\
\text { No.5.11.1.(e) i.e. payment of outstanding Annual Listing Fee of the } \\
\text { Exchange. }\end{array}$ \\
\hline 20 & S.G. Power Limited & 2015 & -do- \\
\hline
\end{tabular}




\section{Z-Score}

In 1968 Edward Altman introduced Z-score measure for predicting insolvency and distress of firms. Altman's model is used to predict the probability of bankruptcy that may help to determine the survival of the firm. Same may be achieved by analyzing diverse financial ratios but the difficulty arises in its susceptibility of miss interpretation, such as, debt ratio representing high leverage may show higher liquidity ratio as well. As generally accepted that number of univariate models may lead to uncertain results, therefore Altman's proposed model gives a sensible solution. According to his solution a linear combination of four to five most relevant firm's financial ratio along with respective weights are used to determine company's solvency. This model lays its foundation on multiple discriminant analysis (MDA) for patterns recognition and to find linear combinations of objects for the purpose of classification into two or more groups.

Many later studies have used an Altman's model making it widely accepted for analysis. Since 1995 it has been used for credit analysis of companies from emerging markets. Researchers, such as, Francis (1990), Dichev (1998), Griffen and Lemmon (2002), Han, Jenning and Noel (1992), Stone (1991), and many others have used Z- Score in their studies resulting in determination of significant results. In the beginning this model was developed and tested only for such publically held manufacturing companies which were identical in size. But later on z'- score and z''- scores were designed and used for private and non-manufacturing companies.

Z- Score is another widespread analysis technique based on five financial ratios with appropriately chosen weights. Five ratios included in Z-score are profitability, leverage, liquidity, solvency and activity ratios. All mentioned ratios must be statistically significant without intercorrelation among themselves. Summation of five measures returns a score by which firms might be divided into two priori groups either non-distress or distress. A firm could be heading towards insolvency if Z-score is less than 1.1 benchmark value and it will be in grey zone if Z-score is 1.1 $\leq Z \leq 2.60$ and in safe region if greater than 2.60 .

The final model is stated as below:

$$
Z=0.012 X_{1}+0.014 X_{2}+0.033 X_{3}+0.006 X_{4}+0.999 X_{5}
$$

Value of $\mathrm{Z}$, as an overall model, is calculated by incorporating the values of individual variables in above linear equation. Variable $X_{1}$ is calculated via dividing the Working capital by Total assets, $X_{2}$ via dividing Retained earnings by Total assets, $X_{3}$ via dividing earnings before interest and taxes by total assets, $\mathrm{X}_{4}$ via dividing market value equity by total liabilities, $\mathrm{X}_{5}$ via dividing Sales by total assets,

\section{Ohlson's O-Score}

An alternate of Altman's Z-Score is a formula introduced by Dr. James Ohlsonin 1980called OScore. This formula also has a capability to forecast bankruptcy within two years of performance. O-Score combines nine factors that are coefficient weighted linear combination of financial ratios taken from company's reports. Some analysts believe it better than Z-Score. The main reason is its application on larger sample size, such as up to 2000 firms, whereas Z-Score applies up to 66 companies. The $\mathrm{O}-\mathrm{Score}$ model is stated in the following equation.

O-Score $=-1.32-0.407 \mathbf{A S}+6.03 \mathbf{L M}-1.43 \mathbf{W C M}+0.757$ ICR -2.37 ROA -1.83 FTDR$1.72 \mathbf{L}+0.285 \mathbf{Y}-0.521 \mathbf{C I N I}$

Probability of Failure $=\mathrm{P}=\exp (\mathrm{O}-\mathrm{Score}) / 1+\exp (\mathrm{O}-\mathrm{Score})$

The firm's solvency is determined on the bases of probability of failure i.e. P value (as mentioned above). If $\mathrm{P}$ value is greater than 0.5 , it is signal that company could move towards insolvency within two years and $\mathrm{P}$ less than 0.5 shows that firm will remain solvent. Whereas:

$\mathbf{A S}=$ Adjusted Size; this is a measure that helps to determine the size of the company in term of its asset. It is calculated by taking logarithm of a company's asset at a particular time T.

$\mathbf{L M}=$ Leverage Measure: This variable calculates company's leverage in order to determine the company's dependency on debt. Higher dependency on debt may result in high risk. 
$\mathbf{W C M}=$ Working Capital. In a situation when a company is endowed with a sufficient assets and the company's profitability shows a positive trends but still faces liquidity problem to meet its short terms obligations. WMC is calculated via dividing the company's variable working capital by its total assets

ICR = Inverse Current Ratio. A firm's current financial ratio is calculated via dividing current liabilities by current assets

ROA = Return on Assets determines the profitability of the company. ROA is calculated when we divide net income by total assets.

FTDR = Fund To Debt Ratio. This variable measures the company's capacity to finance its debts from its operational income only? It is calculated by dividing operating income (pretax income + depreciation) by total liabilities.

$\mathbf{L}=$ Liquidity. It is measured by a dummy variable. After observing the firm's position of the total liabilities and total assets the value of the dummy variable is decided. If total current liability upsurges the total current assets than it will be record as 1 otherwise 0 .

$\mathbf{Y}=$ A dummy variable telling about the profitability of the firm. $\mathrm{Y}$ is computed as 1 if a company has negative profit for consecutive two years otherwise 0 .

CINI = Change in Net Income: CINI takes into consideration of positive or negative change in net income over the recent past two years, it is measured by dividing $\mathrm{NI}(\mathrm{t})-\mathrm{NI}(\mathrm{t}-1)$ with $\mathrm{NI}(\mathrm{t})+$ $\mathrm{NI}(\mathrm{t}-1)$.

\section{Data Analysis and Findings}

To test the above proposed hypotheses all variables including liquidity, leverage, performance, profitability and turnover ratios are measured for 20 bankrupt non-financial firms of Pakistan. ZScore and O-score model are assessed by employing stepwise discriminant analysis to develop the discriminant variables with their respective coefficients as shown in Table 2 and Table.

Table 2. Estimated Results of Five Variable of Z-score Model

\begin{tabular}{crrcrc}
\hline Company & \multicolumn{1}{c}{$\mathbf{X}_{\mathbf{1}}$} & $\mathbf{X}_{\mathbf{2}}$ & $\mathbf{X}_{\mathbf{3}}$ & \multicolumn{1}{c}{$\mathbf{X}_{\mathbf{4}}$} & $\mathbf{X}_{\mathbf{5}}$ \\
\hline 1 & 0.330653199 & 0.007414198 & 0.001878612 & 1.41979475 & 0 \\
2 & -8.09998194 & 0.564092644 & -0.5482951 & 1.98309876 & 0 \\
3 & -0.1840388 & 0.01915883 & 0.061709648 & 2.565233833 & 0.294919347 \\
4 & -0.0160728 & 0.108219349 & -0.0743774 & 0.423445546 & 0 \\
5 & -0.3223332 & 0.114779872 & 0.082611305 & 1.853768354 & 0.718298788 \\
6 & -0.19807166 & 0.057925302 & 0.056930978 & 1.45339834 & 0.489870656 \\
7 & -0.34822604 & 0.051453314 & -0.03063392 & 1.9879878 & 0 \\
8 & -1.16814938 & 0.141568172 & -0.06133140 & 1.89745987 & 0.113397124 \\
9 & -0.78454464 & 0.01015883 & 0.039793452 & 0.74957933 & 0.798341516 \\
10 & -0.38856713 & 0.065644087 & 0.065406891 & 2.98759447 & 0.023719634 \\
11 & -0.533854352 & 0.042679222 & 0.001402186 & 1.23874687 & 0.208626868 \\
12 & -0.78883654 & 0.052241695 & -0.05608734 & 1.98723498 & 0.169767655 \\
13 & -5.8737883 & 3.468027149 & 2.206887159 & 2.9287878 & 0.812657481 \\
14 & 5.163494718 & 1.750725067 & 0.010500243 & 1.8237236 & 1.502466287 \\
15 & -0.0524197 & -0.04726417 & -0.0472009 & 0.3242905 & 0 \\
16 & 0.021342225 & 0.044288263 & 0.046416794 & 0.34982375 & 0.000149518 \\
17 & -0.26986933 & -0.020991649 & 0.03251415 & 0.28734872 & 0.043002681 \\
18 & -0.873516934 & -0.229637116 & 0 & 0.9874589 & 0.301424375 \\
19 & -0.137234766 & 0.028314751 & 0 & 1.94875878 & 0 \\
20 & -0.091326733 & -3.173734653 & 0 & 1.8764877 & 0 \\
\hline & & & & &
\end{tabular}


Table 3. Estimated Results of the Variables of O-score Model

\begin{tabular}{|l|l|l|l|l|l|l|l|l|c|}
\hline Comp & AS & LM & WCM & ICR & ROA & FTDR & L & Y & CINI \\
\hline 1 & 5.8377614 & $2.06 \mathrm{E}-06$ & 0.33065319 & 0.1384 & -0.74 & -0.0049 & 0 & 1 & 0 \\
\hline 2 & 4.8895482 & 1.4794052 & -8.0999819 & 17.896 & -56.41 & -0.3706 & 0 & 1 & 0 \\
\hline 3 & 6.5544929 & 0.5602178 & -0.1840388 & 1.3930 & 1.92 & 0.1102 & 1 & 0 & 0 \\
\hline 4 & 5.0801393 & 0.3591236 & -0.0160728 & 1.0943 & -10.82 & -0.2071 & 1 & 1 & 0 \\
\hline 5 & 7.2676068 & 0.9606494 & -0.3223332 & 2.0765 & -14.93 & -0.0925 & 1 & 0 & -0.1598 \\
\hline 6 & 6.0430741 & 0.7758087 & -0.1980716 & 2.1063 & -5.46 & 0.0152 & 1 & 0 & -1.1184 \\
\hline 7 & 5.9673144 & 0.3853451 & -0.3482260 & 11.554 & -5.83 & 0.0795 & 1 & 0 & 0 \\
\hline 8 & 7.0517191 & 1.6347583 & -1.1681493 & 3.6606 & -17.48 & 0 & 0 & 0 & 0 \\
\hline 9 & 6.4841816 & 1.1147702 & 680935.992 & 4.5131 & -11.1 & 0 & 0 & 1 & 0.7183 \\
\hline 10 & 4.7040733 & 0.3824198 & -0.3885671 & 437.84 & -6.1 & 0 & 1 & 0 & 0 \\
\hline 11 & 6.6767337 & 0.9857449 & -0.5338543 & 3.6983 & -3.91 & 0 & 0 & 0 & 0 \\
\hline 12 & 6.2700643 & 5.166474 & -0.7888365 & 5.6345 & -5.67 & 0 & 0 & 0 & 0 \\
\hline 13 & 4.6439755 & 6.6199124 & -5.8737883 & 8.8724 & -164.31 & 0 & 0 & 0 & -1.0810 \\
\hline 14 & 4.6742823 & 5.6828969 & -5.1634947 & 10.941 & -119.77 & 0 & 0 & 0 & 0 \\
\hline 15 & 5.6466105 & 0.3114453 & 0.05241973 & 1.4571 & -4.6 & 0 & 1 & 1 & -0.1647 \\
\hline 16 & 6.3970147 & 0.9080058 & 0.02134223 & 0.9666 & 1.86 & 0 & 1 & 0 & 0 \\
\hline 17 & 6.9259586 & 0.6130862 & -0.2698693 & 1.7428 & -6.11 & 0 & 1 & 0 & 0 \\
\hline 18 & 5.2787033 & 2.4178168 & -0.8735169 & 2.9047 & -22.66 & 0 & 0 & 0 & 0 \\
\hline 19 & 6.6208178 & 0.5369916 & -0.1372347 & 8.1779 & -2.79 & 0 & 1 & 1 & -0.7265 \\
\hline 20 & 4.8002014 & 0.1881822 & -0.0913267 & 1.9612 & -122.28 & 0 & 1 & 0 & 0 \\
\hline
\end{tabular}

Table 4. Estimated Results Z-Score and O-score Models

\begin{tabular}{|l|l|l|l|}
\hline NO & \multicolumn{1}{|c|}{ Companies } & Z-Score & $\begin{array}{l}\text { P-valuebased } \\
\text { on O-score* }\end{array}$ \\
\hline 1 & Brothers Textile Mills Limited & 0.012652 & 0.117504 \\
\hline 2 & Pangrio Sugar Mills Limited & -0.0955 & 1 \\
\hline 3 & Abdullah Shah Ghazi Sugar Mills Limited & 0.310112 & 0.00313 \\
\hline 4 & Associate Services Limited & 0.001408 & 1 \\
\hline 5 & Azgard Nine Limited (TFC) & 0.729168 & 1 \\
\hline 6 & ICC Textile Limited & 0.498414 & 1 \\
\hline 7 & Suhail Jute Mills Limited & 0.007459 & 1 \\
\hline 8 & Southern Electric Power Co. Limited & 0.110609 & 1 \\
\hline 9 & Paramount Spinning Mills Limited & 0.794082 & 0 \\
\hline 10 & Mukhtar Textile Mills Limited & 0.040036 & 1 \\
\hline 11 & Gulshan Spinning Mills Limited & 0.210088 & 1 \\
\hline 12 & Gulistan Spinning Mills Limited & 0.170936 & 1 \\
\hline 13 & Fateh Sports Wear Limited & 0.880312 & 1 \\
\hline 14 & Fateh Industries Limited & 1.474801 & 1 \\
\hline 15 & Ali Asghar Textile Mills Limited & -0.0009 & 0.999875 \\
\hline 16 & Apollo Textiles Mills Limited & 0.004656 & 0.020328 \\
\hline 17 & Pace (Pakistan) Limited (TFC) & 0.042224 & 0.999999 \\
\hline 18 & Mandviwala Mauser Plastic Industries Limited & 0.293351 & 1 \\
\hline 19 & Dadabhoy Cement Industries Limited & 0.010442 & 0.999986 \\
\hline 20 & S.G. Power Limited & -0.03427 & 1 \\
\hline & *Probability of Failure= P = exp (O-Score)/1+exp(O-Score) & \\
\hline
\end{tabular}

All the calculations have been done on MS Excel work sheets. Finally, the models are developed and results are compared to determine which models have stronger predicting ability. The results are shown as in Table 4.

After applying and estimating both the models on collected data it was found that Z-Score model has predicted bankruptcy of 19 firms and declared 1 firms in grey zone but none of the firm lies in safe zone or declared non-bankrupt. Moreover, for findings of O-Score model 18 firms have been classified as bankrupt and 2 firms has revealed the probability of failure less than 0.5 which according to theory does not lies under the bankrupt category. Besides, all the firms were already declared bankrupt and suspended, the accuracy of both the models has been shown in terms of 
percentage in Table 5.

\begin{tabular}{lcc}
\multicolumn{3}{c}{ Table 5. Classification Results } \\
\hline & Z-Score & O-Score \\
\hline Declared bankrupt & 19 & 18 \\
Grey zone firms & 1 & 0 \\
Declared Non- Bankrupt & 0 & 2 \\
Total no of firms & 20 & 20 \\
Score's predictability in \% & 95 & 90 \\
\hline
\end{tabular}

\section{Conclusion}

This paper identifies the strength of such financial ratios which are most significant in predicting bankruptcy for the non-financial firms of Pakistan. Using a sample of 20 companies which became bankrupt over the 2015-2017 period this study is an attempt to examine the rationality of two the models that either Z score model or O-score is able to better predict firm's failure in Pakistan. Our investigation shows that both models have capacity to predict firm's bankruptcy two years prior to failure with a greater accuracy. We observe that Z-score model has predicted the future bankruptcy with almost 95\% accuracy rate where O-Score model achieved 90\% accuracy rate. The study concludes there is no such major difference among the predicting strength of both models and suggests that both models has been found significant while predicting financial failure of firms. Hence, on the bases of the results hypothesis is accepted that says that both models are equally good in predicting future financial failure of the firms.

Moreover, these models are also a relevant and reliable measuring technique to measure the financial soundness of organizations. Hence, it can be concluded that though these models are based on financial statement analysis and ratios but still their predictabilities are highly accurate and consistent. Further, it plays very important role for financial managers, analysts, investors, and researchers to predict business failure or financial soundness of companies in Pakistan. Additionally, one more aspect that has been noticed is that these models are financial data based but few companies are declared bankrupt due to not meeting non-financial obligation but still their model based results have been found surprisingly significant. This may provide an opportunity to do more research on this aspect as a research gaps.

\section{References}

Altman, E. Haldeman, and Narayanan, P. (1977). ZETA Analysis: A New Model to identify Bankruptcy Risk of Corporations, Journal of Banking and Finance, 1(1), .29-54.

Altman, E. (1991). Techniques for Predicting Bankruptcy and Their Use in a Financial Turnaround, in Levine, S. (ed): Investing in Bankruptcies and Turnarounds: Spotting Investment Values in Distressed Businesses, New York, NY, Harper-Collins.

Altman, E.I. (1968). Financial Ratios, Discriminant Analysis and the Prediction of Corporate bankruptcy, Journal of Finance, September, 589-609

Altman, E.I., Chen, Y., and Weston, F. (1995). Financial Distress and Restructuring Models, Financial Management, 24(2), Summer,1995, 57-75

Beaver, W.(1966)Financial Ratios as Predictors of Failure, Journal of Accounting Research,p.77111

Bandyopadhyay, A. (2006). Predicting probability of default of Indian corporate bonds: logistic and Z-score model approaches. Journal of Risk Finance, 7(3), 255-272.

Begley, J., Ming, J. \& Watts, S. (1996). Bankruptcy classification errors in the 1980s: An empirical analysis of Altman's and Ohlson's models. Review of Accounting Studies, 1, 267-284. https://doi.org/10.1007/BF00570833

Chandler, G., \& Hanks, S. (1998). An examination of the substitutability of founder's human and financial capital in emerging business ventures. Journal of Business Venturing, 13(5), 353-369.

Charitou, A., Neophytou, E., \& Charalambous, C. (2004). Predicting corporate failure: empirical 
evidence for the UK. European Accounting Review, 13(3), 465-497.

Etemadi, H., Anvary Rostamy, A., \& Dehkordi, H. (2009). A genetic programming model for bankruptcy prediction: empirical evidence from Iran. Expert Systems with Applications, 36(2), 3199-3207.

Eljelly, A., \& Mansour, I. (2001). Predicting private companies' failure in the Sudan. Journal of African Business, 2(2), 23-43.

Izan, H. (1984). Corporate distress in Australia. Journal of Banking \& Finance, 8(2), 303-320.

Micha, B. (1984). Analysis of business failures in France. Journal of Banking \& Finance, 8(2), 281-291.

Ohlson, J. (1980). Financial ratios and the probabilistic prediction of bankruptcy. Journal of Accounting Research Spring, 109-131.

Pongsatat, S., Ramage, J., \& Lawrence, H. (2004). Bankruptcy prediction for large and small firms in Asia: a comparison of Ohlson and Altman. Journal of Accounting and Corporate Governance, 1(2), 1-13.

$\mathrm{Xu}$, M., \& Zhang, C. (2009). Bankruptcy prediction: the case of Japanese listed companies. Review of Accounting Studies, 14(4), 534-558.

Zanakis, S., \& Zopounidis, C. (1997). Prediction of Greek company takeovers via multivariate analysis of financial ratios. Journal of the Operational Research Society, 48(7), 678-687. 